\title{
Innovation Forms and Firm Export Performance: Empirical Evidence from ECA Countries
}

\author{
Andrzej Cieślik, Jan Jakub Michałek
}

\begin{abstract}
A B S T R A C T
Objective: The main objective of this paper is to verify empirically the relationship between various forms of innovation and export performance of firms from European and Central Asian (ECA) countries.

Research Design \& Methods: In our empirical approach we refer to the self-selection hypothesis derived from the Melitz (2003) model which proposed the existence of a positive relationship between firm productivity and the probability of exporting. We argue that innovation activities should be regarded as a key element that can increase the level of firm productivity. We focus our analysis on four forms of innovation activities: product, process, marketing, organizational and managerial innovation. The empirical implementation of our analytical framework is based on the probit model, applied to the fifth edition of the BEEPS firm level dataset covering 2011-2014.
\end{abstract}

Findings: Our empirical results indicate that the probability of exporting is positively related to both product and process innovations. The marketing and managerial innovations do not seem to affect positively export performance of firms from ECA countries.

Implications \& Recommendations: It is recommended to develop innovation supporting mechanisms that would target both product and process innovations rather than other forms of innovation in the ECA countries.

Contribution \& Value Added: The originality of this work lies in the use of the multi-country firm level dataset that allows distinguishing between various forms of innovations in the ECA countries.

Article type: research paper

Keywords: $\quad$ ECA countries; firm export performance; innovation forms; probit model JEL codes: F14, P33

Received: 6 September $2016 \quad$ Revised: 18 March 2017 Accepted: 26 April 2017

\section{Suggested citation:}

Cieślik, A., \& Michałek, J.J. (2017). Innovation Forms and Firm Export Performance: Empirical Evidence from ECA Countries. Entrepreneurial Business and Economics Review, 5(2), 85-99, DOI: http://dx.doi.org/10.15678/EBER.2017.050205 


\section{INTRODUCTION}

Innovation is a crucial element of the modernization and development of post-communist countries located in Europe and Central Asia (ECA) and their convergence with the more developed members of the European Union (EU). The measures of innovative activity of firms typically include innovation inputs, such as R\&D spending, as well as innovation output, such as product and process innovations. Previous studies on the role of innovations in the context of firm export performance have focused on developed countries with a high level of innovation activities. These studies distinguished mainly between product and process innovation while other forms of innovation received relatively little attention.

The main goal of this paper is to analyze the relationship between various forms of innovation of firms from the ECA countries and their export performance. In particular, we aim at validating empirically the main hypothesis concerning the positive relationship between various innovation activities and the probability of exporting. In contrast to the previous studies that used either the measures of innovation inputs or outputs, we study the effects of both. Our research hypotheses postulate a positive nexus between the probability of exporting, R\&D spending and four different types of innovation activities: product, process, marketing and managerial innovations. In particular, we aim at determining which of these innovation forms is the most important for firm's probability of exporting. The results of our study can help in proposing a set of policy recommendations that firms from the ECA countries can implement to improve their export performance.

The structure of this paper is as follows. First, we provide the literature review of previous empirical studies on the innovation-exports nexus. Then, we describe the analytical framework and the dataset. Finally, we present our empirical results. The last section summarizes and concludes.

\section{LITERATURE REVIEW}

There is an extensive theoretical literature on the determinants of innovation and their consequences for productivity and exporting. In particular, a key hypothesis in this literature is that innovation is a driver of productivity improvement that in turn can stimulate exports. For example, Atkeson and Burstein (2007) and Constantini and Melitz (2008) have analyzed dynamic industry models to formalize linkages between firm-level productivity and the choices of both to export and to invest in R\&D or adopt new technology. In these models, productivity distinguishes heterogeneous firms, and its evolution is endogenous and affected by innovation decisions at the firm level apart from the stochastic component.

There is also an extensive empirical literature that points to a positive impact of innovation as such on exports at the firm- or plant-level. Two main types of innovation: product innovation and process innovation were studied in this literature. Both types of innovation were found to raise firm's productivity and propensity to export. In particular, product innovations seemed to be more important in determining the export performance of firms than process innovations. However, the empirical evidence on the impact of other forms of innovations such as marketing and managerial innovations is scarce.

The majority of existing empirical studies refer to innovation activities in developed economies, especially in the context of the old EU-15 members. For example, in one of the 
earliest studies Wakelin (1998) employed British firm-level data to report a positive impact of innovation on exports. Similar findings were reported in the majority of studies for other countries: Bernard and Jensen (1999) for the US, Roper and Love (2002) for the UK and Germany, Ebling and Janz (1999), Lachenmaier and Wößmann (2006) and Becker and Egger (2013) for Germany, Caldera (2010) and Cassiman, Golovko and Martínez-Ros (2010) for Spain, Van Beveren and Vandenbussche (2010) for Belgium, and more recently Gkypali et al., (2015) for Greece. ${ }^{1}$

In the context of the new EU member states firm-level empirical evidence on the relationship between innovation and exporting is still scarce. The majority of previous studies devoted to firm-level determinants of export performance used R\&D spending as an indirect measure of innovation and did not distinguish between different types of innovation. For example, in the context of post-communist countries Cieślik, Michałek and Michałek (2012a,b; 2014; 2015) confirmed the positive relationship between R\&D expenditure and the probability of exporting using the BEEPS data.

One of the few studies that explored the relationship between innovation and export activities of firms exception was done by Damjan, Kostevc and Polanec (2010) in Slovenia. They confirmed the importance of spending on R\&D and product innovation for probability of exporting. More recently, Cieślik and Michałek (2016) attempted to verify empirically the hypothesis concerning the importance of innovations for firm involvement in export activities using BEEPS firm-level data for Poland. In particular, they examined not only the relationship between R\&D activity and the likelihood of exporting, but also analyzed the importance of different forms of innovation for the export performance. Their empirical results confirmed the positive role of R\&D spending for exporting, while the results obtained for various forms of innovations were less clear-cut. In particular, they found that only marketing innovations could matter for exporting. However, these results should be treated with caution due to the very small sample size.

Subsequently, Cieślik, Michałek and Szczygielski (2016) studied the relationship between various types of innovations and export performance of Polish firms over the period of 2008-2010 using the Polish CIS data. They controlled for human and physical capital endowment, firm size (employment size groups), the level of technological sophistication of a sector as well as the presence of foreign capital. However, they did not control for the level of productivity. They found that the likelihood of exporting by Polish firms was positively related to both product and process innovations, firm's size, the share of university graduates in employment and foreign ownership.

Similar results were also reported by Brodzicki and Ciołek (2016) in a direct survey panel of 470 Polish manufacturing industry firms. However, only process and organizational innovations were found to increase the probability of exporting. Also Brodzicki (2016) studied the relationship between the extent of innovation and the extent of internationalization in the cross-sectional sample of firms from Poland. He found that productivity was a principal driver of firm exports and firm internationalization. He also found some support for the causality between innovation and internationalization.

\footnotetext{
${ }^{1}$ The problems associated with the use of survey data on innovations in econometric studies are discussed in Mairesse and Mohnen (2010).
} 
It is important to note, however, that the results of previous studies for particular countries may not generalize to the whole group of the ECA countries. Therefore, in our paper we attempt to investigate empirically whether various innovative activities contribute to increased efficiency of firms from ECA countries and whether they improve their ability to compete and stay at international markets. First, in contrast to previous studies conducted for selected EU countries, our study is based on multicountry firm-level dataset, based on individual firm-level data collected by the World Bank. This allows us to study the relationship between various forms of innovative activities and exporting for firms from ECA countries.

Second, in contrast to previous empirical studies, we focus both on sources of innovations such as domestic $R \& D$, the use of foreign technologies as well as the innovation outcomes. The use of foreign technology will be proxied by the purchase of foreign licenses by domestic firms as well as the involvement of foreign companies in the host country. In addition, we will distinguish and examine the relative importance for exports of four types of innovation outcomes: product, process, marketing and managerial innovations. This allows us to identify the relative importance of specific types of innovation activities for exporting of firms from ECA countries, which are still much less innovative when compared to companies from the old EU-15 member states.

In addition, our study will allow formulating specific recommendations for economic policy for firms from ECA countries, especially for policies that encourage specific forms of innovation in these countries which still differ from the old EU member states in terms of the level of economic development. As regards possible conclusions for economic policy for the old EU-15 countries, the findings of the previous studies suggest that policy instruments should be targeted towards specific innovations rather than innovation input, if these countries want to improve their export competitiveness in world markets. In particular, some authors of the previous studies focused on the old EU-15 countries have argued that subsidies and other programs aiming at product innovations should be on average more likely to cause entry into export markets than general expenditures on R\&D or legal environments which particularly favor process innovations. In this paper we attempt to verify this recommendation in the context of the ECA countries.

\section{MATERIAL AND METHODS}

In our empirical approach we refer to the self-selection hypothesis derived from the Melitz (2003) model. This model proposed the existence of a positive relationship between firm productivity and export performance, i.e. that more productive firms self-select into foreign markets. The majority of empirical studies find support for the theoretical prediction of this model having controlled for a number of firm characteristics which may affect their export performance. ${ }^{2}$

Our dependent variable indicating the export status of firm $i$ is denoted by $Y_{i}^{*}$. Instead of observing the volume of exports, we observe only a binary variable $Y_{i}$ indicating the sign of $Y_{i}^{*}$, i.e. whether the firm sells its output in the domestic market (local,

\footnotetext{
${ }^{2}$ According to surveys by Wagner $(2007,2012)$ of empirical studies based on firm-level data from different countries exporters and importers were more productive that non-exporters and non-importers. In particular, his surveys provide extensive evidence in favor of the self-selection hypothesis.
} 
regional or national) or it exports. Moreover, we assume that the variable $Y_{i}^{*}$ follows $Y_{i}^{*}=\mathbf{X}_{\mathbf{i}} \boldsymbol{\Theta}+\varepsilon_{i}$ where the error term $\varepsilon_{i}$ is independent of $\mathbf{X}_{\mathbf{i}}$ which is a vector containing explanatory variables that affect exports with the first term equal to unity for all $i, \boldsymbol{\Theta}$ is the vector of parameters on these variables that needs to be estimated and $\varepsilon_{i}$ is assumed to be normally distributed with a zero mean.

Our dependent variable follows a binary distribution and takes the value 1 when the firm exports and 0 otherwise:

$$
Y_{i}= \begin{cases}1 & \text { if } Y_{i}^{*}>0 \\ 0 & \text { if } Y_{i}^{*}=0\end{cases}
$$

We can obtain the distribution of $Y_{i}$ given $\mathbf{X}_{\mathbf{i}}$. Hence, the probability that a firm exports can be written as:

where:

$$
P\left(Y_{i}=1 \mid \mathbf{X}_{\mathbf{i}}\right)=\Phi\left(\mathbf{X}_{\mathbf{i}} \boldsymbol{\Theta}\right)
$$

$\Phi($ ) - denotes the standard normal cumulative distribution function (cdf).

Our study is based on "EBRD-World Bank Business Environment and Enterprise Performance Survey" (BEEPS) data collected by the World Bank and the European Bank for Reconstruction and Development in the post-communist countries located mainly in Europe and Central Asia (ECA). The main objective of the BEEPS survey was to obtain feedback from enterprises in the aforementioned countries on the state of the private sector. The survey examined the quality of the business environment. The survey questions concerned the identification of firm, sector of activity, legal and economic status, characteristics of managers and size of the firm, the infrastructure of services in analyzed country, economic performance and key characteristics of reviewed firms, as well as stakeholders, e.g. employers organizations, employees organizations, local government, central government, ICT industry, SMEs, academics, etc.

Our sample includes only the period 2011-2014 for which the BEEPS $V$ data was collected. Almost $60 \%$ of surveys in all countries were made in year $2013 .^{3}$ The BEEPS surveys covered both the manufacturing and services sectors and are representative of the variety of firms according to sector and location within each country. The number of firms operating in the service sector was relatively small compared to the manufacturing sector. Therefore, it was not possible to perform estimations separately for the manufacturing and service sectors. Moreover, particular industries within each sector can differ with respect to their capital intensity and export performance. Therefore, to control for heterogeneity across industries we used industry-specific effects in addition to individual firm characteristics in our estimating equations.

In all countries where a reliable sample frame was available, the sample was selected using stratified random sampling. ${ }^{4}$ However, only a small proportion of firms was sampled every year. This means that the application of panel data analysis is not possible. Therefore, we used the standard probit procedure on the pooled crosssection dataset without controlling for individual firm effects but we control for

\footnotetext{
${ }^{3}$ The numbers of observations (surveys) per year were as follows: 2884 in 2011, 1833 in 2012,13435 in 2013 and 4287 in 2014.

${ }^{4}$ The only exception was Albania. The details concerning the sampling methodology are explained in the Sampling Manual available at: http://www.enterprisesurveys.org/Methodology/.
} 
country-specific and industry-specific effects. ${ }^{5}$ In the majority of cases the data includes about 250-350 observations per country. The larger samples of firms are available for Russia (3012), Turkey (833) and Ukraine ((767).

Our dependent variable indicating the export status of the firm takes the form of a binary variable. It takes value zero if the firm sells its output only in the domestic market, and one otherwise, i.e. if it sells also some of its output abroad. In our study we selected a number of explanatory variables chosen from the survey, which should reflect the important characteristics of firms and the innovation efforts of analyzed firms. The description of all variables used in the empirical study is presented in the Table $1 .{ }^{6}$

Table 1 Variables used in the empirical analysis

\begin{tabular}{|c|c|}
\hline Export & $\begin{array}{l}\text { Binary variable that takes the value } 1 \text { if the establishment is exporting and } \\
\text { zero if not }\end{array}$ \\
\hline Lprod & $\begin{array}{l}\text { Natural logarithm of productivity expressed as total amount of annual sales } \\
\text { per full time employee }\end{array}$ \\
\hline Lsize & $\begin{array}{l}\text { Natural logarithm of the number of permanent, full-time employees of this } \\
\text { firm at end of last fiscal year }\end{array}$ \\
\hline Uni & Percentage of full time employees who completed a university degree \\
\hline Fo & $\begin{array}{l}\text { Binary variable indicating whether the percentage owned by private foreign } \\
\text { individuals is larger than none }\end{array}$ \\
\hline age $^{7}$ & Variable indicating how many years elapsed since the foundation of the firm \\
\hline share_gov & Percentage of assets owned by government/state \\
\hline Innov_product & $\begin{array}{l}\text { Binary variable describing whether new products/services were introduced } \\
\text { over last } 3 \text { years }\end{array}$ \\
\hline Innov_process & $\begin{array}{l}\text { Binary variable describing whether new production/supply methods were } \\
\text { introduced over last } 3 \text { years }\end{array}$ \\
\hline Innov_management & $\begin{array}{l}\text { Binary variable describing whether new organizational/ management prac- } \\
\text { tices were introduced over last } 3 \text { years }\end{array}$ \\
\hline Innov_marketing & $\begin{array}{l}\text { Binary variable describing whether new marketing methods were intro- } \\
\text { duced over last } 3 \text { years }\end{array}$ \\
\hline R_D & $\begin{array}{l}\text { Binary variable describing whether there was a spending on R\&D over last } \\
3 \text { years }\end{array}$ \\
\hline Folicences & $\begin{array}{l}\text { Binary variable describing whether the firm used technology licensed from a } \\
\text { foreign-owned company }\end{array}$ \\
\hline
\end{tabular}

Source: own elaboration.

\section{RESULTS AND DISCUSSION}

In this section we report and describe two sets of our estimation results. First, we show the results of our baseline estimations in Table 2. Then, we present the results of our sensitivity tests in Table 3.

\footnotetext{
${ }^{5}$ The list of countries in our sample is shown in Table A1 in the Appendix.

${ }^{6}$ Their summary statistics are reported in Table A2 while the simple bilateral correlations between the explanatory variables are reported in Table $\mathrm{A} 3$ in the Appendix. The results presented in Table A3 demonstrate that the highest correlation, equal 0.567 , exist between marketing and management innovations. The other forms of innovations are also positively correlated (close to 0.47 ). Thus, the interpretation of estimators of various forms innovations should be treated with caution.

${ }^{7}$ The variables age and share_gov were used only in the robustness tests reported in Table 3.
} 
Table 2. Baseline estimation results for ECA countries over the 2011-2014 period

\begin{tabular}{|c|c|c|c|c|}
\hline VARIABLES & (1) & (2) & (3) & (4) \\
\hline \multirow[t]{2}{*}{ Lprod } & $-0.0438 * * *$ & $-0.0276 * * *$ & $0.0360 * * *$ & $0.0733 * * *$ \\
\hline & $(0.00537)$ & $(0.00557)$ & $(0.0103)$ & $(0.0107)$ \\
\hline \multirow[t]{2}{*}{ innov_product } & $0.258 * * *$ & $0.248^{* * *}$ & $0.235^{* * *}$ & $0.199 * * *$ \\
\hline & $(0.0353)$ & $(0.0361)$ & $(0.0373)$ & $(0.0384)$ \\
\hline \multirow[t]{2}{*}{ innov_process } & 0.0367 & -0.00453 & $0.130 * * *$ & $0.0786^{*}$ \\
\hline & $(0.0399)$ & $(0.0409)$ & $(0.0420)$ & $(0.0431)$ \\
\hline \multirow[t]{2}{*}{ innov_management } & 0.0334 & $0.0773^{*}$ & 0.0193 & 0.0559 \\
\hline & $(0.0408)$ & $(0.0418)$ & $(0.0430)$ & $(0.0442)$ \\
\hline \multirow[t]{2}{*}{ innov_marketing } & $-0.0846 * *$ & -0.0618 & $-0.103 * *$ & $-0.0778 *$ \\
\hline & $(0.0390)$ & $(0.0400)$ & $(0.0409)$ & $(0.0422)$ \\
\hline \multirow[t]{2}{*}{ R_D } & $0.473 * * *$ & $0.433 * * *$ & $0.364 * * *$ & $0.319 * * *$ \\
\hline & $(0.0427)$ & $(0.0437)$ & $(0.0449)$ & $(0.0461)$ \\
\hline \multirow[t]{2}{*}{ Uni } & $-0.00453 * * *$ & $-0.00393 * * *$ & $0.00127 * *$ & $0.00212^{* * *}$ \\
\hline & $(0.000440)$ & $(0.000456)$ & $(0.000520)$ & $(0.000540)$ \\
\hline \multirow[t]{2}{*}{ Lsize } & $0.230 * * *$ & $0.209 * * *$ & $0.274 * * *$ & $0.263^{* * *}$ \\
\hline & $(0.0108)$ & $(0.0113)$ & $(0.0117)$ & $(0.0123)$ \\
\hline \multirow[t]{2}{*}{ Fo } & $0.615^{* * *}$ & $0.619 * * *$ & $0.475 * * *$ & $0.456 * * *$ \\
\hline & $(0.0462)$ & $(0.0471)$ & $(0.0489)$ & $(0.0502)$ \\
\hline \multirow[t]{2}{*}{ Folicenses } & $0.337^{* * *}$ & $0.320 * * *$ & $0.240^{* * *}$ & $0.213^{* * *}$ \\
\hline & $(0.0367)$ & $(0.0376)$ & $(0.0394)$ & $(0.0405)$ \\
\hline \multirow[t]{2}{*}{ Constant } & $-1.002 * * *$ & $-0.984 * * *$ & $-2.455 * * *$ & $-2.759 * * *$ \\
\hline & $(0.0757)$ & $(0.0808)$ & $(0.177)$ & $(0.183)$ \\
\hline sectoral effects & \begin{tabular}{|l|} 
No \\
\end{tabular} & yes & no & yes \\
\hline country effects & No & no & yes & yes \\
\hline Observations & 11866 & 11866 & 11866 & 11866 \\
\hline Log likelihood & -5575 & -5285 & -4992 & -4698 \\
\hline Mc Fadden's Pseudo R2 & 0.130 & 0.176 & 0.221 & 0.267 \\
\hline
\end{tabular}

Standard errors in parentheses, $* * * p<0.01,{ }^{* *} p<0.05, * p<0.1$

Source: own calculations in STATA.

In column (1) of Table 2 we report the benchmark results on the relationship between various forms of innovation activities and export performance obtained from the specification in which we control for a number of individual firm characteristics but not for individual sectoral and country effects. The innovation activities of firms include the measures of product, process, management and marketing innovations as well as their R\&D spending. The control variables include firm productivity, firm size, firm ownership, the stock of human capital measured by the percentage of workers with the tertiary degrees, and the use of foreign licenses.

The estimated parameter on the productivity variable is statistically significant already at the $1 \%$ level of statistical significance but surprisingly displays a negative sign. Out of four different forms of innovation outcomes only two are statistically significant. The estimated parameter on product innovation is significant at the $1 \%$ level and displays a positive sign, while the parameter on marketing innovations is statistically significant at the $5 \%$ level, but displays an unexpected negative sign. In addition, the estimated parameter on 
the R\&D spending is also statistically significant at the $1 \%$ level and displays a positive sign. Moreover, the majority of our control variables are statistically significant and display expected signs. In particular, firm size, foreign ownership and the use of foreign technology are positively related to exporting. However, the estimated parameter on the share of workers with tertiary degrees (uni) displays an unexpected negative sign.

In column (2) we report estimation results obtained from the specification in which we control for broad sectoral effects. The benchmark category was basic manufacturing. The majority of individual sectoral effects were statistically significant. For example, the other manufacturing and textiles sectors were more export oriented compared to the benchmark category while food, construction and wholesale less export oriented. The inclusion of the sectoral effects did not have a major impact on statistical significance and signs of the estimated parameters on our measures of innovation activity as well as the control variables. The main difference is that the estimated coefficient on management innovations becomes positive and statistically significant at the $10 \%$ level, while the coefficient on marketing innovations lost its previous statistical significance.

In column (3) we report estimation results obtained from the specification in which we control for country effects. The reference country was Albania. The majority of individual country effects were statistically significant. For example, almost all new EU members are more export oriented countries compared to Albania, while the majority of the former members of the Soviet Union are less export oriented. The inclusion of country effects had a significant impact on estimators of four variables. First, the sign of the estimator of labor productivity variable changed the sign to a positive one and was still statistically significant already at the $1 \%$ level which is in line with predictions of Melitz (2003) model. This result confirms the importance of controlling for individual country effects and reflects differences in the level of development amongst analyzed countries. Second, the process innovation variable became statistically significant at the $1 \%$ and displayed a positive sign. Third, marketing innovation variable became statistically significant at the $5 \%$ level but surprisingly displayed a negative sign, while the management innovation variable lost its statistical significance. Finally, the uni variable, describing the stock of human capital in the firm, became positive and statistically significant at the $5 \%$ level, which is in line with expectations and results obtained in other studies.

Finally, in column (4) we report the estimation results obtained from the specification in which we control for both sectoral and country effects. These results are similar to those reported in the column (3). The major difference is that the estimated parameter on the marketing innovation variable remained statistically significant, but only at the $10 \%$ level with a surprising negative sign, while the statistical significance of the process innovation variable decreased from the 1 to $10 \%$ level. In conclusion we can state that product innovations are more important in comparison to process innovations in the analyzed group of ECA countries as the value of the estimator and statistical significance are higher in the case of product innovations compared to process innovations. This result is in line with a number of previous studies for other, more developed countries. In addition, it was found that other forms of innovations such as management and marketing innovations were not important for exporting. Moreover, the R\&D expenditure was also found to be positively related to exporting. Finally, the internationalization of firms through foreign capital participation and the use of foreign licenses were also important for export performance. 
The instability of estimated coefficients on marketing and management innovation variables that probably results from a relatively high level of correlations between them requires additional sensitivity tests which are provided below. In order to check the robustness of our results and explore further the role of innovations we made some additional estimations. In particular, in our estimated equations we added two variables frequently used in other empirical studies. The first variable age is describing the number of years elapsed since the foundation of the firm. Typically, the expectation is that older firms should have more experience and should be more competitive so the expected sign of this variable is positive. The second variable share_gov describes the percentage of assets owned by the state/government. In some studies the sign of this parameter is negative since state owned firms are sometimes less efficient in comparison to private ones. The estimation results for extended specifications that control for both sectoral and country effects are reported in Table 3.

In column (1) we report the estimation results with two additional variables, i.e. age and share_gov, jointly. Since these estimations are obtained controlling for sectoral and country effects they should be compared to the baseline results shown in column 4 of Table 2. It can be noted that these results are very similar to those from Table 2 . The variable share_gov displays the expected negative sign but the estimated coefficient is statistically significant at the $10 \%$ level only, while the estimator of age variable is statistically not significant at all. The remaining explanatory variables display the same signs and statistical significance with the exception of marketing innovations variable which now becomes statistically significant at the 5 and instead of $10 \%$ level.

In the estimation results shown in column (2) of Table 3 we eliminated the variable age, which was statistically not significant in previous estimations reported in column (1). In these estimation results the variables share_gov and innov_marketing became statistically not significant. Thus, they were dropped from the specification reported in the last column.

Finally, the estimation results presented in column (3) contain only statistically significant variables. All variables used in the final specification display the expected signs. In particular, the estimated coefficient on product innovations variable displays a positive sign and is statistically significant at the $1 \%$ level. The coefficient on the process innovation variable is also positive but its value is smaller, and it is statistically significant at the $10 \%$ level only.

Thus, our sensitivity tests confirm that out of four different forms of innovation outcomes only two are statistically significant and positively related to export performance. Management innovations and marketing innovations do not seem to be statistically significant for exporting in the case of ECA countries. The estimated parameter on the measure of innovation input, i.e. R\&D spending, always displays the expected positive sign and is statistically significant at the $1 \%$ level. In addition, all our control variables are statistically significant and display expected signs. In particular, firm size, foreign ownership, foreign licenses and the share of workers with tertiary degrees are statistically significant at the $1 \%$ level of statistical significance and are positively related to exporting. 
Table 3. Robustness tests with firm age and government share for ECA countries over the 20112014 period

\begin{tabular}{|c|c|c|c|}
\hline VARIABLES & (1) & (2) & (3) \\
\hline \multirow[t]{2}{*}{ Lprod } & $0.0702 * * *$ & $0.0715 * * *$ & $0.0748 * * *$ \\
\hline & $(0.0108)$ & $(0.0108)$ & $(0.0107)$ \\
\hline \multirow[t]{2}{*}{ Age } & 0.00185 & & \\
\hline & $(0.00128)$ & & \\
\hline \multirow[t]{2}{*}{ share_gov } & $-0.00333^{*}$ & -0.00317 & \\
\hline & $(0.00196)$ & $(0.00196)$ & \\
\hline \multirow[t]{2}{*}{ innov_product } & $0.209 * * *$ & $0.208 * * *$ & $0.188^{* * *}$ \\
\hline & $(0.0387)$ & $(0.0385)$ & $(0.0376)$ \\
\hline \multirow[t]{2}{*}{ innov_process } & $0.0771^{*}$ & $0.0930 * *$ & $0.0784^{*}$ \\
\hline & $(0.0434)$ & $(0.0420)$ & $(0.0407)$ \\
\hline \multirow[t]{2}{*}{ innov_management } & 0.0532 & & \\
\hline & $(0.0445)$ & & \\
\hline \multirow[t]{2}{*}{ innov_marketing } & $-0.0848 * *$ & -0.0586 & \\
\hline & $(0.0425)$ & $(0.0387)$ & \\
\hline \multirow[t]{2}{*}{ R_D } & $0.324 * * *$ & $0.325^{* * *}$ & $0.314^{* * *}$ \\
\hline & $(0.0464)$ & $(0.0460)$ & $(0.0452)$ \\
\hline \multirow[t]{2}{*}{ Uni } & $0.00215^{* * *}$ & $0.00216^{* * *}$ & $0.00214^{* * *}$ \\
\hline & $(0.000545)$ & $(0.000543)$ & $(0.000538)$ \\
\hline \multirow[t]{2}{*}{ Lsize } & $0.257^{* * *}$ & $0.265^{* * *}$ & $0.263^{* * *}$ \\
\hline & $(0.0129)$ & $(0.0124)$ & $(0.0122)$ \\
\hline \multirow[t]{2}{*}{ Fo } & $0.496 * * *$ & $0.492^{* * *}$ & $0.453^{* * *}$ \\
\hline & $(0.0526)$ & $(0.0524)$ & $(0.0500)$ \\
\hline \multirow[t]{2}{*}{ Folicenses } & $0.208^{* * *}$ & $0.203^{* * *}$ & $0.212^{* * *}$ \\
\hline & $(0.0408)$ & $(0.0407)$ & $(0.0403)$ \\
\hline \multirow[t]{2}{*}{ Constant } & $-2.718 * * *$ & $-2.741 * * *$ & $-2.781 * * *$ \\
\hline & $(0.185)$ & $(0.184)$ & $(0.183)$ \\
\hline sectoral effects & yes & Yes & yes \\
\hline county effects & yes & Yes & yes \\
\hline Observations & 11722 & 11804 & 11913 \\
\hline Log likelihood & -4633 & -4665 & -4721 \\
\hline Mc Fadden's Pseudo R2 & 0.268 & 0.268 & 0.266 \\
\hline
\end{tabular}

Standard errors in parentheses, ${ }^{* * *} p<0.01,{ }^{* *} p<0.05,{ }^{*} p<0.1$

The number of observations increases with the elimination of some variables.

Source: own calculations in STATA.

\section{CONCLUSIONS}

In this paper we investigated the relationship between various forms of innovation and export performance of firms from the ECA countries using the probit model and the BEEPS $V$ firm level data set covering the period 2011-2014. Our empirical approach referred to the Melitz (2003) theoretical model which emphasized the role of firm productivity in export performance. We argued that various forms of innovation should be regarded as key factors in increasing the level of firm productivity, having controlled for a number of firm characteristics. Our estimation results indicated that the probability of 
exporting was positively related to both product and process innovations, labor productivity, R\&D spending, firm size, the share of university graduates in productive employment, foreign capital participation and the use of foreign licenses. Management and marketing innovations were not found to be statistically significant determinants of export performance. These results suggest that from the policy perspective, financial support for the development of new products and processes as well as R\&D activities should have a positive impact of export performance of firms from the ECA countries. In particular, supporting product innovation should be highly desirable. In contrast, the implications of financial support for marketing and management innovations for exporting were far less clear. These results, however, should be verified in future studies for particular countries and broader samples covering a larger number of years.

\section{REFERENCES}

Atkeson, A., \& Burstein, A. (2007). Innovation, firm dynamics, and international trade (NBER working paper No. 13326). Cambridge, MA: The National Bureau of Economic Research.

Becker, S.O., \& Egger, P.H. (2013). Endogenous product versus process innovation and a firm's propensity to export. Empirical Economics, 44, 329-354.

Bernard, A., \& Jensen, J.B. (1999). Exceptional export performance: cause, effect, or both? Journal of International Economics, 47, 1-25.

Brodzicki, T. (2016). Innovation intensity as a driver of firm's internationalization intensity. Evidence for Poland. Ekonomia, Rynek, Gospodarka, Społeczeństwo, 46, 11-43.

Brodzicki, T., \& Ciołek, D. (2016). Determinanty działalności eksportowej polskich firm produkcyjnych. Gospodarka Narodowa, 2(282), 59-76.

Caldera, A. (2010). Innovation and exporting: evidence from Spanish manufacturing firms. Review of World Economy, 146(4), 657-689.

Cassiman, B., Golovko, E., \& Martínez-Ros, E. (2010). Innovation, exports and productivity. International Journal of Industrial Organization, 28(4), 372-376.

Cieślik, A., Michałek, J., \& Michałek, A. (2012a). Determinanty działalności eksportowej polskich przedsiębiorstw. Gospodarka Narodowa, 7-8(251-252), 67-84.

Cieślik, A., Michałek, J., \& Michałek, A. (2012b). Export activity in Visegrad 4 countries: firm level investigation. Ekonomia, Rynek, Gospodarka, Społeczeństwo, 30, 6-22.

Cieślik, A., Michałek, J., \& Michałek, A. (2014). The influence of firm characteristics and export performance in Central and Eastern Europe: comparisons of Visegrad, Baltic and Caucasus States. Entrepreneurial Business and Economics Review, 2(1), 7-18.

Cieślik, A., Michałek, J., Michałek, A., \& Mycielski, J. (2015). Determinants of export performance: comparison of Central European and Baltic firms. Finance a Uver, 65(3) , 211-229.

Cieślik, A., \& Michałek, J. (2016). Innowacje a działalność eksportowa polskich przedsiębiorstw. International Business and Global Economy, 2(2), 323-337.

Cieślik, A., Michałek, J., \& Szczygielski, K. (2016). Innovations and export performance: firm-level evidence from Poland. Entrepreneurial Business and Economics Review, 4(4), 11-28.

Constantini, J.A., \& Melitz, M.J. (2008). The dynamics of firm-level adjustment to trade liberalization. In E. Helpman, D. Marin \& T. Verdier (Eds.), The organization of firms in a global economy (pp. 107 -141). Cambridge, MA: Harvard University Press. 
Damijan, J.P., Kostevc, C., \& Polanec, S. (2010). From innovation to exporting or vice versa? World Economy, 33(3), 374-398.

Ebling, G., \& Janz, N. (1999). Export and innovation activities in the German service sector. Empirical evidence at the firm level (ZEW discussion paper 99-53). Mannheim: Zentrum fur Europäische Wirtschaftsforschung.

Gkypali, A., Rafailidis, A., \& Tsekouras, K. (2015). Innovation and export performance: do young and mature innovative firms differ? Eurasian Business Review, 5(2), 397-415.

Lachenmaier, S., \& Wößmann, L.W. (2006). Does innovation cause exports? Evidence from exogenous innovation impulses and obstacles using German micro data. Oxford Economic Papers, 58(2), 317-350.

Mairesse, J., \& Mohnen, P. (2010). Using innovation surveys for econometric analysis. In B.H. Hall \& N. Rosenberg (Eds.), Economics of Innovations (vol. 2, ch. 26.). Amsterdam: North-Holland.

Melitz, M.J. (2003). The impact of trade on intra-industry reallocations and aggregate industry productivity. Econometrica, 71(6), 1695-1725.

Roper, S., \& Love, J.H. (2002). Innovation and export performance: evidence from the UK and German manufacturing plants. Research Policy, 31(7), 1087-1102.

Van Beveren, I., \& Vandenbussche, H. (2010). Product and process innovation and firms' decision to export. Journal of Economic Policy Reform, 13(1), 3-24.

Wagner, J. (2007). Exports and productivity: a survey of the evidence from firm-level data. World Economy, 30(1), 60-82.

Wagner, J. (2012). International trade and firm performance: a survey of empirical studies since 2006. Review of World Economy, 148, 235-267.

Wakelin, K. (1998). Innovation and export behaviour at the firm level. Research Policy, 26(7-8), 829-41. 


\section{APPENDIX}

Table A1. The list of countries analyzed and the number of observations on labor productivity

\begin{tabular}{|c|c|c|c|}
\hline \multirow{2}{*}{ Country } & \multicolumn{3}{|c|}{ Summary of Iprod } \\
\hline & Mean & Std. Dev. & Frequency \\
\hline Albania & 14.31475 & 1.459064 & 342 \\
\hline Belarus & 18.90565 & 1.165908 & 285 \\
\hline Georgia & 10.09093 & 1.512932 & 289 \\
\hline Tajikistan & 10.26632 & 1.617868 & 252 \\
\hline Turkey & 11.00044 & 2.20712 & 833 \\
\hline Ukraine & 11.16808 & 1.170125 & 767 \\
\hline Uzbekistan & 16.98649 & 1.533923 & 365 \\
\hline Russia & 13.95404 & 1.304657 & 3021 \\
\hline Poland & 12.53481 & 1.886507 & 390 \\
\hline Romania & 11.60442 & 1.477842 & 476 \\
\hline Serbia & 15.23636 & 1.152075 & 333 \\
\hline Kazakhstan & 15.10829 & 1.018941 & 430 \\
\hline Moldova & 12.15994 & 1.384795 & 312 \\
\hline Bosnia \& Hercegovina & 11.26366 & 0.950644 & 296 \\
\hline Azerbaijan & 9.480009 & 1.214444 & 248 \\
\hline FYR Macedonia & 14.16691 & 1.287866 & 343 \\
\hline Armenia & 15.79516 & 1.159174 & 243 \\
\hline Kyrgyz & 13.40486 & 1.150492 & 215 \\
\hline Mongolia & 16.89435 & 0.980459 & 324 \\
\hline Estonia & 10.88395 & 1.058498 & 243 \\
\hline Kosovo & 10.28185 & 1.445028 & 179 \\
\hline Czech Rep. & 14.34824 & 1.445675 & 215 \\
\hline Hungary & 16.63346 & 1.384401 & 193 \\
\hline Latvia & 9.789768 & 1.467226 & 270 \\
\hline Lithuania & 11.36614 & 1.178445 & 223 \\
\hline Slovak Rep. & 10.75806 & 1.515367 & 172 \\
\hline Slovenia & 11.64111 & 1.286459 & 243 \\
\hline Bulgaria & 10.61182 & 1.10446 & 273 \\
\hline Croatia & 12.98574 & 0.843683 & 322 \\
\hline Montenegro & 10.28256 & 1.167177 & 102 \\
\hline Total & 13.04625 & 2.57869 & 12199 \\
\hline
\end{tabular}

Source: own calculations in STATA.

Table A2. The summary statistics for all ECA countries

\begin{tabular}{|c|c|c|c|c|c|}
\hline Variable & Obs & Mean & Std. Dev. & Min & Max \\
\hline Iprod & 12.199 & 13.046 & 2.578 & -3.4012 & 25.798 \\
\hline age & 15.724 & 14.392 & 11.717 & 0 & 174 \\
\hline share_gov & 15.720 & 0.878 & 7.651 & 0 & 99 \\
\hline R_D & 15.752 & 0.106 & 0.308 & 0 & 1 \\
\hline uni & 15.883 & 37.197 & 33.694 & 0 & 100 \\
\hline Isize & 15.778 & 3.027 & 1.253 & 0 & 9.306 \\
\hline multi & 15.314 & 15.569 & 22.052 & 0 & 100 \\
\hline fo & 15.883 & 0.078 & 0.269 & 0 & 1 \\
\hline folicenses & 15.688 & 0.146 & 0.353 & 0 & 1 \\
\hline innov_product & 15.797 & 0.242 & 0.428 & 0 & 1 \\
\hline innov_process & 15.796 & 0.197 & 0.398 & 0 & 1 \\
\hline innov_management & 15.795 & 0.212 & 0.409 & 0 & 1 \\
\hline innov_marketing & 15.778 & 0.230 & 0.421 & 0 & 1 \\
\hline
\end{tabular}

Source: own calculations in STATA. 
Table A3. The correlations between explanatory variables for all CEE countries

\begin{tabular}{|c|c|c|c|c|c|c|c|c|c|c|c|c|c|}
\hline I & Iprod & age & $\begin{array}{c}\text { share_ } \\
\text { gov }\end{array}$ & R_D & uni & Isize & multi & fo & $\begin{array}{c}\text { Fo } \\
\text { licences }\end{array}$ & $\begin{array}{l}\text { Innov_- } \\
\text { product }\end{array}$ & $\begin{array}{l}\text { Innov__ } \\
\text { process }\end{array}$ & $\begin{array}{c}\text { innov }_{-} \\
\text {management }\end{array}$ & $\begin{array}{l}\text { innov__ } \\
\text { marketing }\end{array}$ \\
\hline Lprod & 1 & & & & & & & & & & & & \\
\hline age & -0.061 & 1 & & & & & & & & & & & \\
\hline share_gov & 0.131 & 0.106 & 1 & & & & & & & & & & \\
\hline R_D & 0.02 & 0.075 & 0.003 & 1 & & & & & & & & & \\
\hline uni & 0.157 & -0.154 & -0.027 & 0.002 & 1 & & & & & & & & \\
\hline Isize & 0.033 & 0.285 & 0.132 & 0.165 & -0.096 & 1 & & & & & & & \\
\hline multi & 0.018 & 0.043 & -0.004 & 0.087 & -0.028 & $-2 \mathrm{E}-04$ & 1 & & & & & & \\
\hline fo & 0.05 & 0.032 & 0.008 & 0.065 & 0.007 & 0.191 & 0.016 & 1 & & & & & \\
\hline Folicenses & -0.047 & 0.057 & -0.002 & 0.134 & -0.001 & 0.17 & 0.023 & 0.131 & 1 & & & & \\
\hline innov_product & 0.037 & 0.062 & -0.004 & 0.328 & 0.008 & 0.128 & 0.138 & 0.072 & 0.134 & 1 & & & \\
\hline innov_process & 0.061 & 0.058 & 0.003 & 0.327 & 0.009 & 0.144 & 0.093 & 0.054 & 0.113 & 0.487 & 1 & & \\
\hline innov_management & 0.073 & 0.057 & 0.005 & 0.317 & 0.027 & 0.162 & 0.096 & 0.078 & 0.11 & 0.371 & 0.476 & 1 & \\
\hline innov_marketing & 0.076 & 0.038 & 0.005 & 0.296 & 0.029 & 0.117 & 0.121 & 0.067 & 0.11 & 0.37 & 0.405 & 0.567 & 1 \\
\hline
\end{tabular}

Source: own calculations in STATA. 


\section{Authors}

The contribution share of authors is equal and amounted to $50 \%$ each of them.

\section{Andrzej Cieślik}

Professor of University in the Area of International Economics in the Faculty of Economic Sciences of the University of Warsaw (Poland). PhD in Economics by the University of Warsaw (Poland). Correspondence to: Prof. Andrzej Cieślik, PhD, University of Warsaw, Faculty of Economic Sciences, ul. Długa44/50, 00-241 Warsaw, Poland, e-mail: cieslik@wne.uw.edu.pl

\section{Jan Jakub Michałek}

Professor of University in the Area of International Economics in the Faculty of Economic Sciences of the University of Warsaw (Poland). PhD in Economics by the University of Warsaw (Poland). Correspondence to: Prof. Jan Jakub Michałek, PhD, University of Warsaw, Faculty of Economic Sciences, ul. Długa44/50, 00-241 Warsaw, Poland, e-mail: michalek@wne.uw.edu.pl

\section{Acknowledgements and Financial Disclosure}

The article came into being within the project no. 2015/17/B/HS4/01077 entitled' Innovation activity and export competitiveness in the new EU member countries' financed by the National Science Center (NCN) conducted by Andrzej Cieślik and Jan Jakub Michałek in the years 2016-2018.

The authors would like to thank the anonymous referees for their useful comments, which allowed to increase the value added of this article.

\section{Copyright and License}

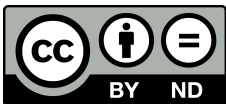

This article is published under the terms of the Creative Commons Attribution - NoDerivs (CC BY-ND 4.0) License http://creativecommons.org/licenses/by-nd/4.0/

Published by the Centre for Strategic and International Entrepreneurship - Krakow, Poland 
